\title{
Talking about Li Zhi's theory of childlike innocence and its ideological origin
}

\author{
Tian Changhong \\ Pingxiang University, Pingxiang, Jiangxi, 337055, China
}

\section{Key words: Childlike innocence, Heart, Real, Pure}

\begin{abstract}
In this regard, different people, different cultures have their own different answers. Confucius thought that is "benevolence"; for Mencius, it is "righteousness" ;Cheng Zhu considered "justice"; Wang Shouren considered the "conscience", and $\mathrm{Li}$ Zhi proposed the concept of "innocence" in 'Book Burning' and 'Book Burning II'. Li Zhi believes that there is no difference between a saint and an ordinary person, Buddha and the masses, or ancients and modernists, everyone has a childlike innocence. "Childlike innocence is sincerity ", means that innocence is really, alternatively, it is an utter innocence. "Men with innocence are pure and innocent with human nature", from which we can find that $\mathrm{Li}$ Zhi believes that innocence is pure and innocent human nature. Just as so called "the streets all saints Mr. yang", for both the sage and the dull, innocence is the same. This kind of natural "childlike innocence", is not only a kind of innate moral idea, but already contains the individual consciousness. This is the progress of Li Zhi's childlike innocence..
\end{abstract}

\section{Introduction}

Li Zhi, whose alternative name is Wu Zhuo, is a famous thinker and grand master of Taizhou school of thought live in Fujian, Quanzhou. He was born in the sixth year of Jiajing Emperor of Ming Dynasty(AD 1527) and died in the wanli thirty year of Ming Emperor (AD 1602). Confucianism, Taoism and Buddhism have emphasized, " Study the root cause of life and death, Explore the whereabouts of life" . And the essential of Li Zhi's whereabouts is mainly about the relationship between dependence and real life. 'Book Burning' and 'Book Burning II' are Li Zhi's representative work, which mainly include some essays, letters, political thesis, random thoughts and a small amount of poetry. The language and view point in it are sharp, it is not only object to " Obey Confucius's view of right and wrong ",but also criticize the idea of Buddhish, on the background of that time that is the deviant. The 'Childlike Innocence' is one of the representatives of 'Book Burning' and 'Book Burning II' and also an important ideological enlightenment in the history of Chinese thought.

What is the most precious thing for a man? What is the most fundamental thing? In this regard, different people, different cultures have their own different answers. Confucius thought that is "benevolence"; for Mencius, it is "righteousness" ;Cheng Zhu considered "justice"; Wang Shouren considered the "conscience", and Li Zhi proposed the concept of "innocence"[1] in 'Book Burning' and 'Book Burning II'. Li Zhi believes that there is no difference between a saint and an ordinary person, Buddha and the masses, or ancients and modernists, everyone has a childlike innocence. " Childlike innocence is sincerity ", [1]means that innocence is really, alternatively, it is an utter innocence. "Men with innocence are pure and innocent with human nature", from which we can find that Li Zhi believes that innocence is pure and innocent human nature[1]. Just as so called "the streets all saints Mr. yang", for both the sage and the dull, innocence is the same. This kind of natural "childlike innocence", is not only a kind of innate moral idea, but already contains the individual consciousness. This is the progress of Li Zhi's childlike innocence. 


\section{The basic meaning of Li Zhi's "childlike innocence"} 2.1 Zhi Li's "childlike innocence" inherits and develops the innate goodness of Confucian and Meng Zi.

The so-called "innocence" put the natural human desire as the conscience. "Childlike innocence, the beginning of the heart.", Childlike innocence is the beginning of life, as it is not affected by the outside world pollution and interference of the natural and sincere heart. Since there is no pollution of the outside world, such a heart is perfect and with all the wonderful possibilities. If there is no such a conscious conscience, men would lose reality, individual value and significance, and cannot exist as a real subject. "If you loss the innocence, you will lose your heart, then lose the reality. If the man is not true, the intention will be lost"[1]. After regulated by universal standard, innocence will be lost easily. Only retain this childlike innocence, can we get full of infinite change and development possibilities. Childlike innocence is sincerity which can determine whether you are real human. If there is no sincerity and lose a real human, there is no more original mind. Zhi li set wether have childlike innocence as the standard of judging the real person. Lost childlike innocence, also lost the qualification to become a real person. If a person is not sincere, he will lose the possibility of becoming an independent personality.

"Baby, the beginning of a man; sincerity, the initial of heart". Everyone has been a baby before[1], and everyone has a childlike innocence. Children are the beginning of life. Sincerity is not only the iniyial of our heart, but also the consciousness of human personality and subjective value. Some people say that the best feng shui masters are children, because they are the closest one to nature and can feel the good or bad parts of nature. Why is it easy to lose childlike innocence in the process of learning? In Zhi Li's perspective, People get knowledge from their eyes and ears in the Enlightenment period, they learn from what they are seeing and hearing and lose their innocence". With growing, peolple get a lot of "truth" by what they have seen and heard, then focus on the truth and lost their innocence. Then, with more seeing and hearing, people think the "truth" is good, "innocence" is evil. With the expension of individuals' realm of senses, people would like to pursue a variety of reputation, and try to develop a better reputation; Men known the disadvantage of bad reputation then try to hide. Learn to deceit to raise the so-called beauty and hide the so-called evil, then completely lost innocence. "When lose innocence, the speech would not be sincere; politics is not reliable; what is more, when you try to write an article, the language fails to express the meaning. [1]Lose childlike innocence, so that the city is not a "Saint", but all over the dummy. These dummy, with false heart, tell lies, false thing, write false paper. "Dummy enjoy in listening to your lies, false paper and false language." [1]Then led to the result: "everything is not false, then no joy. All is false, what distinguishes the dwarves?" [1]Therefore, this kind of "childlike innocence" is not false but true, not false but sincere, it should be a kind of state of mind that has not been eroded by the official ideology of innocence and simplicity.

Why do the saints would not lose their childlike innocence when they grow up, mainly because that the purpose of reading is to keep their childlike innocence. "longitudinal reading, but also to protect your childlike innocence and do not lose yourfelf."[1] Even if the saints read more, they also recognize the importance of childlike innocence, they can guard the childlike innocence instead of losing it. If you read the book which can help you understand the rationale, but make you lose your childlike innocence, you'd better do not read it. "If peolple read more scholars may lose their innocence, Saints would not write so many books?" [1]Therefore, readers get justice from books which would be used to protect the childlike innocence.

\subsection{To admit that there is selfish childlike innocence.}

What exactly "childlike innocence" is? Zhi Li recoganize the rationality of selfish through the the willing of the guarding childlike innocence and liberating personality. He said: "Dress and eat is human natural. Apart from food and clothing, there is nothing. All things in the world can be defined as clothing and food." He believes that each person as an individual, have their own specific ideas and requirements, have the desire to maintain their own lives, have the desire to dress for dinner. These 
specific ideas, demands and desires, makes everyone's "selfish". Altruistic activities may have an individual, but would not have the hearts of the people, because people want to eat their meals, make their lives and protect their own interests. This also is a kind of childlike innocence.

\subsection{Criticize the pseudo Taoist school with "childlike innocence".}

Zhi Li believes that the "six classics", "nalects of Confucius" and "Mencius" are the flattering words and the language of praise for pseudo thinkers[2]. He defined traditional Confucian classics boldly. "Who knows that most of those words are not come from saints?" He believes that some of these classics was not come from saint and not observed; Even some word come from saints, but also "Not a prescription for the special disease"[2], it is targeted with background words. "Medicine for sick, party to hold, is thought to be classical thought?" Zhi Li put forward the research questions of these sages. He thinks that their true and false are not convinient to distinguish textual criticism, so cannot be regarded as a classic. What's more, we can learn from the words "six classics, the Analects of Confucius , Mencius , all passed from mouth to mouth , absolutely cannot get the initial heart from the language. Alas! I have lost an Dezhen Zhengda saint with innocence and the Holy word!"[2] that these books were used as a shield to scare people by descendants of classical and pseudo scientists, there is no way to compare them with a sincere heart. Zhi Li believes that the guardian of childlike innocence need a certain distance from Daoism, which has its progress and profundity at that time.

\subsection{With childlike innocence, advocate "natural".}

Li Zhi live in a time with stereotyped writing, in which time the style of writing are mostly unable to express the independent thinking. While Li Zhi has put forward, "All those articles in this word are all comes from innocence." The sincere heart is the essence of article. That is to say, the best of the world, all are comes from author's true feeling and nature. All works of art must show author's inner feelings and desires of life heartily. A true artist is must be who can maintain innocence in a socialized, rationalized and secularized word. "I do not know the situation, deeply attached. The living can die, the dead can live." Articles come from childlike innocence and true temperament are excellent work. "The secret of East country, the excellent work of West country, the article of Lisao , Ban and Ma; the poetry of Tao, Xie, Liu, Du; the novels of officials of low ranks; the song of Song/Yuan Dynasty, celebrities"[2]. Aims at literary decadent style, he advocating the "innocence thoery" which prevent insincerity use true intention.

\section{The ideological origin of childlike innocence}

\subsection{Rooted in Lao zhuang. "Innocence" should be taken from the Taoist philosophy}

Lao Zi said: "Special gas is as soft as a baby?"[3] "As infant", "return to infancy", "moral is deep, just like a baby"[4] and so on, these views are all described the baby's gas special, thick, pure and pure german. It also provides a pure and simple philosophy for the interpretation of "innocence" as "pure and initial heart” by Zhi Li.

Then Zhuang zi inherited Lao Zi's thought and carried it forward. "Autumn water" article said: "keep and do not lose, is true."[5] Talking about the magical thoughts of "baby" and "innocence". Li Zhi's "childlike innocence" has extracted the idea of Lao Zi and Zhuang Zi.

\subsection{Absorption and utilization of Zen}

Li Zhi absorbs the change of Zen and the nature of pure, so that he can extricate himself from the painful social reality and realize the proposition of the theory of natural human nature. Then jump off and sit alone thinking, abandon the world of Zen, just to be a happy Buddha. Attempts to take pride and ambition to spend their lives to save endangered countries and the suffering people. This is also the initial heart stressed by Li Zhi's "childlike innocence", focusing on "false innocence" efforts. He turned into the crowd from the sky, and towards the social reality, trying to help people from the real life.

\subsection{Embodies the spirit of Yangming School of mind}

Essentially, "Childlike innocence" is not only close to Yang Ming but also close to Buddha. Article from Yangming's "teaching record volume I" named "heart"said: " The key of the body is a justice, no indecent assault, this is your own's true.” And another artcle from "Reply Lu Yuanjing" named "conscience" said: "no bad natuer, no bad gays. Conscience is in our body and all the same. 
But we should shield dark shelter to the body, so we must learn how to stop it. The conscience in our body is not changed."[6] This words are the same as Li Zhi's "innocence" theory, in which people aslso lose their initial heart because more hearing and seeing. Yang Ming is also said that conscience is easy to be effected by other objects and "faint in the material desire". So ancients said "Although we don't read, the childlike innocence is also solid and comfortable. Even eading more, we also use it to protect childlike innocence and make it firm”[1].

Wang Yangming's "true self" is the conscience fully rendered in the human body, and the "conscience" is a natrue that everyone has, which will be affected by material desires, rely on "learning" skills to protect. While "learning" is no gain for the "conscience", this is the reason that Li Zhi think truth comes from seeing and hearing, and oppose t "innocence" obstacles.

This road is the transfer of Li Zhi's teacher, Wang Bi. Wang Bi said in the "Eastern quotations" that conscience is "Do a work without tweaking reluctantly", he consider that conscience is not an actual, we born with it and we can get it as long as we do as nature. The study of Wang Bi, all with "do not make a hand for the wonderful", as a bird singing in the mountains Petals drop and waters flow, thirsty to drink, hunger and food, is all nature fully rendered. This emphasizes the intuitive nature and know self thought, which makes contribution to Li Zhi's "innocence" thoery with "absolutely false innocence".

\section{Li Zhi's theory of "childlike innocence" and Lao Zi's " Daily loss for Daoism", Zhuang Zi's "truth" and "Remain truth"}

The forty-eighth chapter of "Lao Zi" also mentioned that "To learn more and more, to be a taoist and to be less. To be less and less then become inaction. Doing nothing but doing everything. Take the world often with nothing, and everything, not enough to take the world."[7] "To learn more and more", is talking about learning, it is necessary to accumulate when explore the knowledge of activities, the more knowledge accumulated, the better, so "more"'". "For learning", refers to the study of knowledge. After Learning a long time, knowledge is increasingly profound. Just like spring seedlings, we never see them grow but it does; dropping out of school is just like the knife stone,never see it is damaged but it does become less. " to be a taoist and to be less " refers to the increased repair, a spiritual realm, should realize that "Tao" can not be said and named; what's more, the less desire and feelings the better,only so can we experience the human thoery, so we should "to be less". The realm is required here. " be enlightened " relys on self-cultivation, it needs to wait and see......... and return to simplicity. To be less, just like the pure, or a baby, "Simplicity, with little selfishness and desire." The best state is that the real master, high educated people, who may be like a child, still remain innocent and naive romantic. "Who can remain naive in this filthy word"[8]. Life is like a opened cup with dust, which need to calm down and clean up every day. People should know their benefits and keep their losses. As the memtioned by modernist artist named Picasso, "it took thirty years to learn how to draw like a master. It took a lifetime to learn to draw like a child." As Lao Zi Lao said the basic of daoism is to be more natural and better, gradual reduction of diet, all human activities should be naturally and do not make a difference.

$\mathrm{Li}$ Zhi is able to understand the truth of Lao Zi's "daily loss". So he explained that "innocence" suddenly lost after growing up is caused by the smell from outside replaced the initial heart, the heart can not be empty and that was its "really" like. "In the beginning, the information from the word come into the our heart, then replace the innocence." The early lose of chidren is caused by their eyes and ears. While growing up, the reason is "the truth of the information comes to our heart, and replace the innocence."[1] With the growth of age, a lot of prejudice comes to our heart, then loss the "childlike innocence". The loss of childlike is because people get to know more truth and information, and realize "good", "not good named bad"[1], so as to cover the bad for good, imperceptibly lost innocence. This is the so-called non classical education, after learning the sage words, lose the original pure heart and real value. Thus, the natural goodness of man is lost, and the inner basis of goodness is lost. Lao $\mathrm{Zi}$ proposed that people should not be tired of things, not to be the object of service, not to be alienated by things, people live a simple life. "Hiding more, then die"[9]. Rich possession of goods will inevitably lead to heavy losses. Love fame, people will work hard, fear, loss 
and become foolish. People with too many treasures will be look aftered by rpbbers, and not only lose property but also more likely to harm themselves. Ruin of the country must caused by strong evil.

Zhuang zi consider that real is the most intrinsic nature of human, "Man with the real inside, god moved outside, is rare real."[5] The reason why "truth" is valuable is that it is the most essential part of the existence of human beings, and only if it holds the essence, can it be regarded as a human being. So how do you remain real? The method proposed by Zhuang zi is bound to get rid of benevolence, righteousness, propriety, wisdom and moral consciousness and norms. Let your heart with its own words and deeds; Then you should give up the things outside of the chase and focus on life itself.

Li Zhi's view is very similar to that of Zhuang Zi. According to his view, to guard the good childlike innocence, we must eliminate the temptation to interfere, and obey our own subjective wishes. So Li Zhi stressed the need to maintain the " essential ", "broken", "true"'". "essential" is "the human nature." That is to go deep into the realm of ontology, pay attention to the combination of human nature, and pursue the essence of the article. "Broken" is to get rid of "the information from the word" and other consciousness ,to get rid of scientists said the"truth comes from information", even to golden laws and precious rules, such as "six classics", "the Analects of Confucius", "Mencius" and other books; all sorts of physical restrictions should also be broken. "True" is " sincerity ", means a special "pure true ", which is a kind of real hearted that have not been polluted by informations comes from our word. Li Zhi attaches great importance to the life of the "true" (the truth of life, the truth of the soul, the true feelings,ture things, true words and true Daoism). The people he love, must be sincere man and true hero; His friends must can die for each other; His knowledge must talk about life and death; The literature he love must be genuine, ture words. This is also the essence of Lao Zi and Zhuang Zi philosophy which understood by Li Zhi, and injected into the "childlike innocence" theory.

\section{Conclusions}

The first limitation of Li Zhi's childlike innocence theory is its uncertainty. In the "childlike innocence", have not make a detailed description of the concept of childlike innocence and sincerity. What is childlike innocence? And what is the truth? It was still in a state of confusion that might have been clear in his mind but cannot tell. Then for a fake Connotation -- " truth from information", the definition of false is lack of persuasion power. Secondly, Li Zhi's childlike innocence theory is an important part in the development of his thought, but it is wrapped in the ideological framework of his religious spirit. Innocence is the base of Buddha, if your heart is not true, thought is not pure, and think Buddha but cannot feel it, learn Buddhism but cannot pure your heart, it will be hard for you to become a buddha. It need a sincere heart. Instead of "before the emotion expressed", Li Zhi said that the beginning of the people means the "before born by your parents ". To a certain extent it also means empty and nothing.

\section{References}

[1] Li Zhi. Burning Book II, [M] Bejing, Zhong Hua Book Company, 2013, 98.

[2] Li Zhi. Burning Book II, [M] Bejing, Zhong Hua Book Company, 2013, 99.

[3] Wang Bi. Lao Zi Dao De Jin Zhu Xiao Shi, [M] Bejing, Zhong Hua Book Company, 2013, 22.

[4] Wang Bi. Lao Zi Dao De Jin Zhu Xiao Shi, [M] Bejing, Zhong Hua Book Company, 2013, 145.

[5] Guo Qing Fan. Zhuang Zi Ji Shi, [M] Bejing, Zhong Hua Book Company, 2013.

[6] Wang Shou Ren.Zhuang Xi Lu Jiao Shi, [M]Chang Sha: Yue Lu Academy, 2013, 96.

[7] Wang Bi. Lao Zi Dao De Jin Zhu Xiao Shi, [M] Bejing, Zhong Hua Book Company, 2013, 128.

[8] Wang Bi. Lao Zi Dao De Jin Zhu Xiao Shi, [M] Bejing, Zhong Hua Book Company, 2013, 33.

[9] Wang Bi. Lao Zi Dao De Jin Zhu Xiao Shi, [M] Bejing, Zhong Hua Book Company, 2013, 122. 